\title{
Distance Education: An Investigation of Tutors' Electronic Feedback Practices during Coronavirus Pandemic
}

\author{
https://doi.org/10.3991/ijet.v17i04.22563 \\ Atef Odeh AbuSa'aleek ${ }^{(\varpi)}$, Abdullah N. Alotaibi \\ Majmaah University, Al-Majmaah, Saudi Arabia \\ a. odeh@mu.edu.sa
}

\begin{abstract}
The current study investigated the patterns of English language tutors' e-feedback practices during the coronavirus pandemic, learners' response to tutors' e- feedback and the important issues that emerged from efeedback practices. Quantitative and qualitative analysis of the online questionnaire and the semi-structured interviews were performed. The findings indicate that (1) English language tutors concentrate slightly more on local issues than global issues, provide eight main types of e-feedback; clarification requests, general explanations and clarification, questions and commands, repetition, explicit feedback, elicitation and recasts respectively. In addition, tutors employ more written and audio e-feedback compared with the screencast via various online platforms such as Blackboard collaborative tools, Zoom, Microsoft Teams, Email, and WhatsApp. (2) The findings indicate that the students ask for more clarifications, express their understanding of the e-feedback, engage in discussions, comprehend the e-feedback and make successful revisions, express their misunderstanding of the e-feedback and just a few students ignore the efeedback they receive. (3) The qualitative analysis of the semi-structured interviews revealed some important issues such as the tutors' preferences to online learning, the appropriateness of online platform tools in providing e-feedback, ways and timing of providing e-feedback.
\end{abstract}

Keywords—e-feedback, tutors e-feedback, responses to feedback, multimodality

\section{Introduction}

Distance Education is expected to become mainstream globally in the digital era of higher education by 2025 [1], [2]. The timeline is accelerated due to the outbreak of the coronavirus pandemic [3]. The coronavirus pandemic poses major challenges for societies worldwide, with substantial and complicated consequences for institutions of higher education, especially in the area of English language teaching and learning [4]. During this pandemic, switching directly to distance education has fully emerged as an inevitable solution in all schools and universities [5], [6]. 
Integrating technology into the higher education system has extended the way tutors provide their second/foreign language learners with electronic feedback (efeedback). Tutors Practices of e-feedback in higher educational institutions have drawn considerable attention among scholars and academics [7], [8], [9]. Feedback alignment is essential for determining feedback efficiency [10]. In distance education, exposure to different technologies can promote self-regulated learning, as well as the various e-feedback formats, may effectively address the students' needs [11]. Providing e-feedback continues to remain one of the most important discussion topics in language teaching and learning $[9,12]$.

Considerable attention has been paid to feedback practices in general and tutors' efeedback practices in particular [8,9, 13-16]. Those researchers highlight the need for further research on tutors' feedback practices from their perspectives, investigating the best patterns of providing e-feedback. Other studies have indicated that efeedback should not be ignored and avoided because of its efficacy [8, 16]. Many traditional tutors are new to distance education and e-learning and lack academic training on how to teach and provide-feedback online effectively $[17,18]$. There is a need to investigate the tutors' readiness to teach online [19]. In [20] the authors reported that less is known about the extent to which tools influence how tutors deliver various e-feedback and whether this e-feedback influences the nature of learners' responses.

\section{$2 \quad$ Literature review}

In online environments, providing students with effective feedback is difficult, where the physical absence of the tutor and the restrictive nature of most accessible distance learning platforms can create a barrier to providing students with the necessary feedback [21]. In general, tutors' e-feedback is a type of scaffolding mechanism to provide information to the learners in a dialogic way [12]. Furthermore, tutors' feedback is also regarded as a scaffolding mechanism in which tutors support language learners to recognize and identify the various issues and problems in their activities [14]. Tutors' feedback is closely related to student learning [11, 22]. In [23] the authors indicated that feedback comes in various formats based on the context and students' needs such as confirmation of a correct response and the providing of different types of feedback about the activities.

Tutors' e-feedback influenced by sociocultural theory [24], Interaction theory of SLA [25]. The learning process continues and teachers can only create an active learning environment through the interactions between learners and tutors or peers by enabling them to interact and provide feedback [26]. The integration of various technological tools in language teaching and learning has expanded the way tutors afford e-feedback to their learners. Producing and delivering effective and timely e-feedback is considered as daunting task, regardless the tutors' level of online teaching and training [27, 28].

In [20] the authors reported that producing and delivering e-feedback is a complex practice; tutors need to decide if the feedback is directed for local or global issues. 
During the outbreak of the coronavirus pandemic tutors are gradually relying on several supportive digital technologies such Blackboard LMS, WhatsApp, email, Zoom, Microsoft Teams, Google Docs, screencasts, track changes in the word processor to provide their students with e-feedback [12, 29, 30-34].

In distance education, tutors are heavily using various electronic tools for providing e-feedback to English language learners, Blackboard [35], Google Docs, [12, 36, 37]. Other studies used screencasts [30, 32, 38], Audio feedback through MP3 files [39], track changes [40-42], WhatsApp [33].

Previous research on tutors' e-feedback has focused on delivering e-feedback synchronously and asynchronously via more than one electronic tools, screencasts, a free audio add-on (Kaizena), marginal comments [30], Microsoft word \& screencast [20, $31,42]$. In [42] the authors investigated the synchronous and asynchronous tutor efeedback and learner uptake in ESL writing, Tutors' Corrective Feedback and learners' uptake in the EFL Classrooms [43], tutoring and revision [44].

In [30] the author provided e-feedback both micro and macro-level issues via screencast, audio, Written Feedback as marginal comments. Global explanatory feedback delivered via video and written mode, whereas the local explanatory feedback effectively addressed, which lead to effective revisions on average [32]. In [31] the authors used various types of e-feedback namely; explanation, directive, suggestion, praise, question, model and interpersonal feedback. In [45] the authors used four different types of feedback categories (explicit feedback, simple and complex mechanical, and organizational issues) to monitor how learners addressed different types of feedback in their successive drafts. In [13] the authors employed directive, explicit, principled and systematic feedback.

In [42], video feedback was used to address the global writing issues and while Microsoft Word feedback helped learners easily identify "errors" and highlighted the feedback. Oral feedback occurred more on content, structure, and organization, while the written feedback recurrent on the form [20]. Tutors offered e-feedback to their students' assignments on global issues by audio recording more than local issues hence the audio describes the global issues more freely compared with written comments [39]. Alharbi [29] reported that the patterns of asynchronous tutors' e-feedback on learners' writing were corrections, suggestions, directives, questions and statements. Furthermore, the tutors employed both direct and indirect feedback. The tutors' e-feedback affected learners' revisions in terms of global and local issues.

From such evidence, the current study aimed to provide a comprehensive picture of tutors' e-feedback practices during the outbreak of coronavirus pandemic among English language tutors at Majmaah University in Saudi Arabia by answering the following specific research questions:

1. What are the patterns of English language tutors' e-feedback practices during the coronavirus pandemic?

2. How do English language learners respond to tutors' e- feedback from tutors' point of view?

3. What are the important issues that emerged from the tutors' e-feedback practices? 


\section{$3 \quad$ Method}

The present study used a quantitative and qualitative research approaches, in order to obtain data that enriches our understanding of the English language tutors' electronic feedback practices during coronavirus pandemic in various language skills, linguistic and literature courses.

\subsection{Data collection and analysis}

The study was carried out at Majmaah University, Saudi Arabia during the second semester of the academic year of 2019-2020. The university is one of Saudi Arabia's providers of distance education for students during the coronavirus pandemic, delivered online through the Blackboard learning management system. Before the outbreak of the Coronavirus Pandemic, the language skills, linguistic and literature courses were taught in traditional teaching methods.

After the coronavirus pandemic began to spread in the Kingdom of Saudi Arabia, the distance education classes started in the month of March 2020, until the second semester 2021. Distance education was the only optimal solution to maintain learning processes as well as other various activities at times of exceptional situations such as the outbreak of the Coronavirus Pandemic. The English language tutors provided efeedbacks synchronically as well as a synchronically to the students via the university Blackboard learning management system during the period of mass closure of education.

The sample of the study consisted of 40 English language tutors selected randomly from four English departments in the university. The English language tutors belong to different cultural backgrounds and different countries namely; Saudi Arabia, Egypt, Yamen, Pakistan, India, Sudan and Jordan. Furthermore, the English language tutors are native speakers of the Arabic, Urdu, English languages. There was a slight male bias of $77.5 \%$ to $22.5 \%$ female.

\subsection{Settings and participants}

Since the focus of this study was on the tutors' electronic feedback practices during coronavirus pandemic, data were collected from the tutors' responses to online questionnaire. The researchers created and developed online questionnaire with reference to previous studies [12, 29, 46, 47, 48]. The online questionnaire using a five-point Likert scale, from strongly disagree (1) to strongly agree (5) comprised two parts of 35 items. The first part gathered demographic data of the respondents comprised 6 items such as gender, native language, nationality, academic rank, experience in elearning, whether they attend training courses in e-learning before the new COVID 19 Pandemic. The second part comprised 29 items to explore of tutors' electronic feedback practices during coronavirus pandemic. The second part of the questionnaire consisted of six sections namely; content of the feedback, types of e-feedback, modes of e-feedback, format of e-feedback, students responses to the e-feedback from tutors' point of view and issues of electronic feedback. The semi-structured individual inter- 
views were conducted with eight English language tutors, guided by open-ended questions to encourage them to freely share their thoughts and any issues in efeedback. All of the tutors had prior online teaching experience.

Three experts in the field validated the questionnaire. They were requested to check the suitability of the content and the adequacy of items to the aims and the questions of the study. Their suggestions and comments were taken into consideration. The Cronbach's Alpha coefficient was administrated to ensure the reliability of the questionnaire. Cronbach's alpha reliability was determined to be 0.89 , which is considered a very good value from the statistical point of view.

The questionnaire data were analysed using SPSS to get related descriptive statistics including percentage, means and standard deviation. Further, English language tutors' responses to the questionnaire items were categorized into equal interval width, including low (1-2.33), moderate (2.34-3.66), and high (3.67-5).

Semi-structured interviews guided by a set of open-ended questions were conducted with eight English language tutors. The qualitative analysis of the semi-structured interviews revealed some important issues such as the tutors' preferences to online learning, the appropriateness of online platform tools in providing e-feedback, ways and timing of providing e-feedback.

\section{$4 \quad$ Findings}

This section presents findings obtained from the quantitative analysis of the online questionnaire to answer the first two research questions and findings obtained from qualitative analysis of the semi-structured interviews to answer the third research question.

\subsection{The patterns of English language tutors' e-feedback}

In terms of the first research question on the patterns of English language tutors' efeedback practices during the coronavirus pandemic, these patterns are discussed under the following dimensions.

Theme one: Content of e-feedback. English language tutors were asked to respond to three items to identify the content of e-feedback practices they used when teaching English during the coronavirus pandemic. Using mean and standard deviation for the total scores revealed that English language tutors concentrate on both global and local aspects of the e-feedback when they deliver e-feedback to their students. More specifically, the overall mean of English tutors' responses to the three items related to the content of e-feedback practices ranged from 3.78 to 3.88 as shown in Table 1. This shows that the patterns of the content of e-feedback practices both global and local issues fell in the high categories. This finding indicates that English language tutors concentrate slightly more on local issues of the e-feedback such as grammar, vocabulary, punctuation when they deliver e-feedback to their students $(\mathrm{M}$ $=3.88, \mathrm{~S}$. Dev. 1.02) than the global issues such as the content and the organization of 
Paper-Distance Education: An Investigation of Tutors’ Electronic Feedback Practices during...

the task ( $M=3.78$, S. Dev. 0.98). In other words, English language tutors $(68.29 \%)$ agreed and strongly agreed that they provide both global and local e-feedback.

Table 1. Distribution of the content of e-feedback

\begin{tabular}{|l|l|c|c|c|c|c|c|c|}
\hline No & \multicolumn{1}{|c|}{ Items } & SD & D & N & A & SA & Mean & S. Dev. \\
\hline 1 & $\begin{array}{l}\text { I concentrate on global issues when I } \\
\text { deliver e-feedback to my students. }\end{array}$ & 2.44 & 7.32 & 24.39 & 41.46 & 24.39 & 3.78 & 0.98 \\
\hline 2 & $\begin{array}{l}\text { I concentrate on local issues when I } \\
\text { deliver e-feedback to my students. }\end{array}$ & 0.00 & 12.20 & 21.95 & 31.71 & 34.15 & 3.88 & 1.02 \\
\hline 3 & $\begin{array}{l}\text { I concentrate on both global and local } \\
\text { aspects of feedback when I deliver e- } \\
\text { feedback to my students. }\end{array}$ & 2.44 & 2.44 & 26.83 & 41.46 & 26.83 & 3.88 & 0.92 \\
\hline
\end{tabular}

Note. $\mathrm{SD}=$ strongly disagree, $\mathrm{D}=$ disagree, $\mathrm{N}=$ neutral, $\mathrm{A}=$ agree, and $\mathrm{SA}=$ strongly agree. $\mathrm{S}$. Dev. = Standard Deviation

Theme two: Types of English tutors' e-feedback. Various types of English tutors' e-feedback were investigated by asking English language tutors were to respond to eight items to identify the types of e-feedback practices they used when teaching English during the coronavirus pandemic namely; explicit feedback, recasts, clarification request, metalinguistic feedback, elicitation repetition, explanations and clarification, questions and commands.

Using mean and standard deviation for the total scores of each item revealed that English language tutors employed various types of e-feedback. Table 2 shows that the overall mean of English tutors' responses to each category of the types of e-feedback ranged from 3.41 to 4.37 . This shows that the various types of English tutors' efeedback employed when teaching English during the coronavirus pandemic fell in the moderate to high categories. Six items in this section were rated above 3.39 to 4.44 (high category). The two remaining types of e-feedback metalinguistic feedback and recasts were rated in the moderate category with mean scores ranging from 3.41 to 3.61 .

The findings indicate that the most frequently used types of English tutors' efeedback were clarification requests $(\mathrm{M}=4.44$, S. Dev. 0.86) in which the tutors ask the student to repeat his/ her question, utterance when they misunderstood the question or utterance followed by general explanations and clarification $(\mathrm{M}=4.37, \mathrm{~S}$. Dev. 0.76). The other types of are employed in decreasing frequently as follows: questions and commands ( $M=4.17, S$. Dev. 0.96), repetition $(M=4.00, S$. Dev. 0.99) in which the tutors repeat the student error in isolation and adjust their intonation to draw students' attention to the error. Furthermore, explicit feedback $(\mathrm{M}=3.39, \mathrm{~S}$. Dev. 1.05) in which the tutors provide the correct form, and clearly indicate what the student said or wrote was incorrect. In addition to elicitation $(\mathrm{M}=3.83$, S. Dev. 0.76) in which the tutors directly elicit the correct answer from the students by simply repeating just up to the points of error, by using questions to a elicit a correct answer, or by asking the students to modify their question.

The less frequently employed type of e-feedback was recasts $(\mathrm{M}=3.61, \mathrm{~S}$. Dev. 1.01), in which the tutors reformulate and paraphrase the entire or part of a student's utterance or writing, excluding the mistake. In addition to metalinguistic feedback (M 
$=3.41$, S. Dev. 1.21), which includes either comments, information, or questions regarding the well-formedness of the student's utterance or question, without giving the correct form explicitly.

Table 2. Distribution of the types of English tutors' e-feedback

\begin{tabular}{|l|l|c|c|c|c|c|c|c|}
\hline No & \multicolumn{1}{|c|}{ Items } & SD & D & N & A & SA & Mean & S. Dev. \\
\hline 1 & Explicit feedback & 0.00 & 12.20 & 21.95 & 26.83 & 39.02 & 3.93 & 1.05 \\
\hline 2 & Recasts & 0.00 & 14.63 & 34.15 & 26.83 & 24.39 & 3.61 & 1.01 \\
\hline 3 & llarification request & 2.44 & 2.44 & 2.44 & 34.15 & 58.54 & 4.44 & 0.86 \\
\hline 4 & Metalinguistic feedback & 9.76 & 12.20 & 24.39 & 34.15 & 19.51 & 3.41 & 1.21 \\
\hline 5 & Elicitation & 0.00 & 9.76 & 19.51 & 48.78 & 21.95 & 3.83 & 0.88 \\
\hline 6 & Repetition & 2.44 & 4.88 & 19.51 & 36.59 & 36.59 & 4.00 & 0.99 \\
\hline 7 & explanations and clarification & 0.00 & 4.88 & 2.44 & 43.90 & 48.78 & 4.37 & 0.76 \\
\hline 8 & questions and commands & 0.00 & 9.76 & 9.76 & 34.15 & 46.34 & 4.17 & 0.96 \\
\hline
\end{tabular}

Note. $\mathrm{SD}=$ strongly disagree, $\mathrm{D}=$ disagree, $\mathrm{N}=$ neutral, $\mathrm{A}=$ agree, and $\mathrm{SA}=$ strongly agree. $\mathrm{S}$. Dev. = Standard Deviation

Theme three: Modes of delivery of e-feedback. The English tutors employ various modes of delivery of e-feedback. They employ written, audio and screencast of efeedback via a variety of electronic platforms such as Blackboard and WhatsApp when teaching English during the coronavirus pandemic. The analysis of the modes of delivery of e-feedback by using mean and standard deviation for the total scores of each item revealed that English language tutors provide written, audio, and screencast, as well as they, employ more than one mode of e-feedback (oral, video, written) at the same time. More specifically, the overall mean of English tutors' responses to the four items related to the modes of delivery of e-feedback practices ranged from 3.95 to 2.98 as shown in Table 3 .

This shows that the modes of delivery of e-feedback practices employed by English tutors when teaching English during the coronavirus pandemic fell in the moderate to high categories. The analysis of the modes of delivery of e-feedback practices showed that written $(\mathrm{M}=3.95, \mathrm{~S}$. Dev. 0.88) and audio modes $(\mathrm{M}=3.68, \mathrm{~S}$. Dev. 1.33) were most frequently used. Other findings showed that English tutors employ more than one mode of e-feedback (oral, video, written) at the same time, whereas screencasts (video) mode of delivery was less used.

Table 3. Distribution of modes of e-feedback

\begin{tabular}{|l|l|c|c|c|c|c|c|c|}
\hline No & \multicolumn{1}{|c|}{ Items } & SD & D & N & A & SA & Mean & S. Dev. \\
\hline 1 & Audio e-feedback & 7.32 & 17.07 & 14.63 & 21.95 & 39.02 & 3.68 & 1.33 \\
\hline 2 & $\begin{array}{l}\text { Screencasts (video) } \\
\text { e-feedback }\end{array}$ & 26.83 & 17.07 & 14.63 & 14.63 & 26.83 & 2.98 & 1.57 \\
\hline 3 & Written e-feedback & 2.44 & 0.00 & 26.83 & 41.46 & 29.27 & 3.95 & 0.88 \\
\hline 4 & $\begin{array}{l}\text { Mix of e-feedback } \\
\text { (oral, video, written) }\end{array}$ & 12.20 & 14.63 & 12.20 & 43.90 & 17.07 & 3.39 & 1.27 \\
\hline
\end{tabular}

Note. $\mathrm{SD}=$ strongly disagree, $\mathrm{D}=$ disagree, $\mathrm{N}=$ neutral, $\mathrm{A}=$ agree, and $\mathrm{SA}=$ strongly agree. $\mathrm{S} . \mathrm{Dev} .=\mathrm{Standard}$ Deviation 
Theme four: Format of providing and exchanged e-feedback. Based on the descriptive analysis of the format of tutors' e-feedback practices, the tutors use various interactive platforms when providing and exchanged e-feedback with their students namely; namely: Blackboard collaborative tools, WhatsApp, Email and mix of online platforms (Blackboard, email, WhatsApp, Zoom and Microsoft Teams). Using mean and standard deviation for the total scores of each item revealed that English language tutors employed various formats of e-feedback. Table 4 shows that the overall mean of English tutors' responses to each category of the format of e-feedback ranged from 3.07 to 3.88 .

This shows that the various format of e-feedback employed by English tutors. Two items in this section (mix of online platforms and Blackboard collaborative tools) were rated 3.88 to 3.68 (high category). The two remaining formats of e-feedback (WhatsApp, and Email) were rated in the moderate category with mean scores ranging from 3.07 to 3.10 .

The findings indicate that the most frequently used format of delivering and exchanging e-feedback was a mix of online platforms (Blackboard collaborative tools, email, WhatsApp, Zoom and Microsoft Teams), $(\mathrm{M}=3.88$, S. Dev. 1.09), followed by Blackboard collaborative tools $(\mathrm{M}=3.68, \mathrm{~S}$. Dev. 1.28). The less frequently used format of delivering and exchanging e-feedback was email $(\mathrm{M}=3.10, \mathrm{~S}$. Dev. 1.46), followed by WhatsApp ( $\mathrm{M}=3.07$, S. Dev. 1.63).

Table 4. Distribution of format of providing and exchanged e-feedback

\begin{tabular}{|l|l|c|c|c|c|c|c|c|}
\hline No & \multicolumn{1}{|c|}{ Items } & SD & D & N & A & SA & Mean & S. Dev. \\
\hline 1 & Blackboard collaborative tools & 9.76 & 9.76 & 14.63 & 34.15 & 31.71 & 3.68 & 1.28 \\
\hline 2 & WhatsApp & 34.15 & 2.44 & 9.76 & 29.27 & 24.39 & 3.07 & 1.63 \\
\hline 3 & Email & 26.83 & 4.88 & 17.07 & 34.15 & 17.07 & 3.10 & 1.46 \\
\hline 4 & $\begin{array}{l}\text { Mix of online platforms } \\
\text { Blackboard, email, } \\
\begin{array}{l}\text { WhatsApp, Zoom and } \\
\text { Microsoft Teams). }\end{array}\end{array}$ & 2.44 & 9.76 & 21.95 & 29.27 & 36.59 & 3.88 & 1.09 \\
\hline
\end{tabular}

\subsection{The patterns of students' responses to e-feedback}

In terms of the second research question on the patterns of students' responses to efeedback from tutors' point of view during the coronavirus pandemic, these patterns are discussed below. English language tutors were asked to respond to six items to identify the patterns of English language students' responses to e-feedback from tutors' point of view during the coronavirus pandemic. Using mean and standard deviation for the total scores revealed that the students responded to e-feedback in a variety of ways.

More specifically, the overall mean of English tutors' responses to the six items related to the students' responses to e-feedback ranged from 2.68 to 4.10 as shown in Table 5. This shows that the patterns of the students' responses to e-feedback fell in the moderate to high categories. 
Based on the descriptive analysis of the students' responses to e-feedback from tutors' point of view, the findings indicate that the students ask for more clarifications when they got confused about the e-feedback they receive $(M=4.10, S$. Dev. 0.93). Furthermore, the findings show that students express their understanding of the efeedback they receive $(\mathrm{M}=3.95, \mathrm{~S}$. Dev. 0.94), as well as the students engage in discussions regarding the e-feedback they receive $(\mathrm{M}=3.80, \mathrm{~S}$. Dev. 1.09).

The English language tutors reported that the students comprehend the e-feedback and make successful revisions to their writing $(\mathrm{M}=3.66, \mathrm{~S}$. Dev. 0.78). Moreover, the tutors reported that the students express their misunderstanding of the e-feedback they receive $(M=3.27, S$. Dev. 1.27). Finally, the findings indicate that just a few students ignore the e-feedback they receive to their tasks $(\mathrm{M}=2.68, \mathrm{~S}$. Dev. 0.97).

Table 5. Patterns of students' responses to e-feedback

\begin{tabular}{|l|l|c|c|}
\hline No & \multicolumn{1}{|c|}{ Items } & Mean & S. Dev. \\
\hline 1 & My students express their understanding of the e-feedback they receive. & 3.95 & 0.94 \\
\hline 2 & My students express their misunderstanding of the e-feedback they receive. & 3.27 & 1.27 \\
\hline 3 & $\begin{array}{l}\text { My students ask for more clarifications when they got confused about the e-feedback } \\
\text { they receive. }\end{array}$ & 4.10 & 0.93 \\
\hline 4 & My students engage in discussions regarding the e-feedback they receive. & 3.80 & 1.09 \\
\hline 5 & $\begin{array}{l}\text { My students comprehend the e-feedback and make successful revisions to their } \\
\text { writing. }\end{array}$ & 3.66 & 0.78 \\
\hline 6 & My students ignore the e-feedback they receive to their tasks. & 2.68 & 0.97 \\
\hline
\end{tabular}

\subsection{Findings of the qualitative analysis of the interview}

The researcher conducted this semi-structured interview in order to identify English language tutors' thoughts about online teaching in general and e-feedback practices in particular. They were encouraged to clearly share their thoughts and any issues in e-feedback.

In terms of the third research questions explored in this study, the following discussion presents tutors' perceptions of online teaching in general and e-feedback practices. All of the interviewees said that they attended training sessions on the Blackboard learning platform before and during the coronavirus pandemic. One of the interviewees stated, "I have attended some training sessions on how to make the optimal use of the Blackboard. He added, "Regarding my experience in online teaching, it cannot be judged as good or bad because online teaching is a double-edged weapon". Other added, "Online teaching can be so advantageous if both teachers and students make use of all the facilities it provides".

Other interviewees express their fear when there was a direct shift to distance education during the outbreak of COVID-19 Pandemic because many traditional tutors are new to distance education and e-learning and lack academic training on how to teach and provide-feedback online effectively. One of the interviewees stated, "In the beginning, it was a bit challenging to work with new tools but now enjoying it. As we have learned so many different tools and really it was a great way of learning". 
In terms of whether the tutors provide individual or group e-feedback, all of the interviewees reported that they provide both individual and group e-feedback. One of the interviewees stated that "I provide group feedback when I think that majority of students have made a mistake or error". He added, "However, usually I prefer individual feedback since it is motivating, confidence building and draws positive results". Other prefers to provide individual e-feedback more that group e-feedback; he stated, "Individual feedback makes them realize their mistakes and they try to overcome them". Other added, "Different students have different needs, learning styles, and different psychology and therefore it is always more helpful to provide individual feedback rather than group feedback".

In terms of whether the online platforms have the appropriate tools for providing efeedback or not, one of the interviewees stated, "Blackboard provides all the channels needed for providing and exchanging feedback with the students". Other stated, "it is effective to provide e-feedback via Microsoft teams".

With regard to the timing of e-feedback, all of the interviewees reported that they provide e-feedback during and after the classes. One of the interviewees stated, "I provide e-feedback during the conduction of classes and based on the students' needs and sometimes feedback is given after marking quizzes and assignments". Other stated, "I provide feedback after quizzes, assignments, midterm exams and class activities". He added, "I provide feedback for students' answers of quizzes and assignments during classes, mistakes are identified and necessary corrections are made”.

\section{Discussion}

This study was conducted in responding to the challenging concerns in tutors' efeedback in general $[9,12,19]$. More specifically this study conducted to fill the gaps highlighted in recent research surrounding the need for further research on tutors' feedback practices from their perspectives, investigating the best patterns of providing e-feedback, and to what extent tools influence how tutors deliver e-feedback and whether this e-feedback influences the nature of learners' responses [15, 20].

This study adds to current studies by determining the various patterns of English language tutors' e-feedback practices employed during the coronavirus pandemic namely; content of e-feedback practices both global and local issues, types of efeedback practices. In addition, this study presents insight into the various delivery modes of e-feedback (oral, video, written) used by English tutors, the format of providing and exchanged e-feedback via Blackboard collaborative tools, WhatsApp, Email and a mix of online platforms (Blackboard, email, WhatsApp, Zoom and Microsoft Teams). This study presented important findings indicating the patterns of students' responses to e-feedback from tutors' point of view and significant issues emerged from e-feedback practices during the coronavirus pandemic.

Generally, the English tutors concentrate on both patterns of the content of efeedback; global and local issues. More specifically, English language tutors concentrate slightly more on local issues than global issues. This finding is in the line of previous studies in terms of the nature of content issues addressed via the instructor's 
e-feedback on both global and local issues [29, 32, 38, 41, 42]. In [38] the authors reported that tutors prioritized both local and global issues based on the difficulty of the course and the level of students' proficiency and according to the students' needs. This finding is contradicted with $[12,39]$ hence these studies reported that tutors have delivered and directed their e-feedback on global issues rather than local issues because global issues tended to produce more interaction. In [13] the authors reported that tutors' e-feedback was directed to grammatical structures and content and organization, which indicates that e-feedback is effective and should not be ignored.

In terms of types of tutors' e-feedback practices, the finding of this study presents an interesting insight into the various patterns used by the English tutors in formulating their e-feedback in the form of eight main patterns: explicit feedback, recasts, clarification request, metalinguistic feedback, elicitation repetition, explanations and clarification, questions and commands.

This finding supports the previous evidence on tutors' mixed preferences of various patterns in formulating their e-feedback [12, 20, 29, 31, 46, 48, 49].

With regard to modes of delivery of e-feedback, tutors employ written, audio and screencast of e-feedback via a variety of electronic platforms such as Blackboard and WhatsApp when teaching English during the coronavirus pandemic. English language tutors' preferences for the modes of delivery of e-feedback varied. In this regard, tutors employed all the modes in delivering and exchanging e-feedback. The most noticeable finding is that the English tutors preferred both written and oral modes of delivery of feedback compared with the screencast.

This finding supports the previous evidence on tutors' mixed preferences of various modes of delivery of their e-feedback [12, 30, 42, 50]. In [12] the authors reported that the e-feedback provided through written mode/comment is more likely to create more engagement than audio feedback. It is also important to take into consideration the students' variables and mode of delivery of e-feedback, hence, learner proficiency may play an important role in effectiveness [7]. In [51] the author reported that students with low-proficiency benefited more from written e-feedback than those of high-proficiency.

Previous studies confirm the need for combining various modes of delivery in order to maximize opportunities for the students to identify and understand the efeedback [20, 42, 52]. Previous studies compared between written, audio and video modes of delivery of e-feedback $[30,50]$ whereas [20] compared between written and oral modes; [42] compared between video commentary and written feedback. In [52] the authors reported that video feedback has a high level of acceptance among tutors and students.

In terms of the format of providing and exchanged e-feedback, this study has found that English language tutors used various online platforms such as Blackboard collaborative tools, Zoom, Microsoft Teams, Email, and WhatsApp for providing efeedback. This finding supports the previous evidence on tutors' mixed preferences of using various formats of online platforms for providing e-feedback [12, 29, 33, 53, 54].

With regard to the patterns of students' responses to e-feedback, the finding of this study presents an interesting insight into the various patterns of students' responses to 
e-feedback from tutors' point of view. The findings indicate that the students ask for more clarifications, express their understanding of the e-feedback, engage in discussions, comprehend the e-feedback and make successful revisions, express their misunderstanding of the e-feedback and just a few students ignore the e-feedback they receive. This finding is in the line of previous studies in terms of the nature of students' responses to e-feedback addressed by the tutors $[55,56]$. The effective formulation of e-feedback plays an important role in triggering students to engage and use effectively with the feedback [14, 42, 57].

The analysis of the interviews indicates some important issues such as the tutors' preferences to online learning, whether online platforms have the appropriate tools or not for providing e-feedback, ways of providing e-feedback, individual and group efeedback. It is important to take into account how learners successfully receive, engage with, and respond to feedback [58]. The provided feedback to learners is essential for effective learning [59]. In [60] the author reported that there are consequences for tutor participation in e-feedback namely; the number of students in the class, and tutors' stress and demands on their time.

\section{Conclusion}

The purpose of the current study was to determine the patterns of English language tutors' e-feedback practices during the coronavirus pandemic, learners' responses to tutors' e-feedback, and the important issues that emerged from the tutors' e-feedback practices.

The evidence from this study suggests that although some English tutors are new to distance education and lack academic training on how to provide-feedback online effectively; they need to take into consideration the necessity of providing the students with clear, useful, and timely e-feedback and address students' different needs, learning styles. In addition to varying, the modes of delivery of e-feedback and take into account the hearing and sight impairment of the students in order to give all the students the opportunity to understand, negotiate and respond to the e-feedback effectively.

Several limitations to this study need to be acknowledged. First, the sample size is 40 English language tutors; therefore, more research is required to determine the efficacy of tutors' e-feedback practices among a large sample and among different subjects. Second, this study involved only the analysis of tutors' e-feedback practices. Therefore, future studies are recommended to investigate the students' perceptions towards tutors' e-feedback practice in general and to compare their perceptions towards various patterns of e-feedback practices during the coronavirus pandemic because the students are feedback receivers.

\section{$7 \quad$ Acknowledgment}

The authors would like to thank Deanship of Scientific Research at Majmaah University for supporting this work under Project Number No. R-2021-239. 
Paper-Distance Education: An Investigation of Tutors' Electronic Feedback Practices during...

\section{$8 \quad$ References}

[1] Arum and M. L. Stevens, "What Is a College Education in the Time of Coronavirus?," The New York Times, 18-Mar-2020. [Online]. Available: https://www.nytimes.com/2020/ 03/18/opinion/college-education-coronavirus.html [Accessed: 09-Mar-2021].

[2] S. Palvia, P. Aeron, P. Gupta, D. Mahapatra, R. Parida, R. Rosner, and S. Sindhi, "Online Education: Worldwide Status, Challenges, Trends, and Implications," Journal of Global Information Technology Management, vol. 21, no. 4, pp. 233-241, 2018. https://doi.org/10 $.1080 / 1097198 X .2018 .1542262$

[3] J. Ross, E. Bothwell, J. Lau, D. Kellermann, H. Bartlett, P. Vanberkel, and S. P. Amjad, "Will the coronavirus make online education go viral?," Times Higher Education (THE), 13-Mar-2020. [Online]. Available: https://www.timeshighereducation.com/features/willcoronavirus-make-online-education-go-viral [Accessed: 09-Mar-2021].

[4] Z. Draissi and Q. ZhanYong, "COVID-19 Outbreak Response Plan: Implementing Distance Education in Moroccan Universities," ssrn.com, 03-May-2020. [Online]. Available: https://papers.ssrn.com/sol3/papers.cfm?abstract_id=3586783 [Accessed: 01-Nov-2020].

[5] W. Bao, "COVID - 19 and online teaching in higher education: A case study of Peking University," Human Behavior and Emerging Technologies, vol. 2, no. 2, pp. 113-115, 2020. https://doi.org/10.1002/hbe2.191

[6] G. Basilaia and D. Kvavadze, "Transition to Online Education in Schools during a SARSCoV-2 Coronavirus (COVID-19) Pandemic in Georgia," Pedagogical Research, vol. 5, no. 4, 2020. https://doi.org/10.29333/pr/7937

[7] C. Chang, K. J. Cunningham, H. M. Satar, and C. Strobl, "Electronic feedback on second language writing: A retrospective and prospective essay on multimodality," Writing \& Pedagogy, vol. 9, no. 3, pp. 405-428, 2018. https://doi.org/10.1558/wap.32515

[8] T. Chen, "Technology-supported peer feedback in ESL/EFL writing classes: a research synthesis," Computer Assisted Language Learning, vol. 29, no. 2, pp. 365-397, 2016. https://doi.org/10.1080/09588221.2014.960942

[9] M. Henderson, T. Ryan, and M. Phillips, "The challenges of feedback in higher education," Assessment \& Evaluation in Higher Education, vol. 44, no. 8, pp. 1237-1252, 2019. https://doi.org/10.1080/02602938.2019.1599815

[10] M. Fernández-Toro and C. Furnborough, "Evaluating alignment of student and tutor perspectives on feedback on language learning assignments," Distance Education, vol. 39, no. 4, pp. 548-567, 2018. https://doi.org/10.1080/01587919.2018.1520043

[11] G. M. Johnson and A. Cooke, "Self-regulation of learning and preference for written versus audio-recorded feedback by distance education students," Distance Education, vol. 37, no. 1, pp. 107-120, 2016. https://doi.org/10.1080/01587919.2015.1081737

[12] M. A. Saeed and H. S. Al Qunayeer, "Exploring teacher interactive e-feedback on students' writing through Google Docs: factors promoting interactivity and potential for learning," The Language Learning Journal, pp. 1-18, 2020. https://doi.org/10.1080/09571 736.2020.1786711

[13] E. Ene and T. A. Upton, "Learner uptake of teacher electronic feedback in ESL composition," System, vol. 46, pp. 80-95, 2014. http://dx.doi.org/10.1016/j. system. 2014.07.011

[14] D. Carless and D. Boud, "The development of student feedback literacy: enabling uptake of feedback," Assessment \& Evaluation in Higher Education, vol. 43, no. 8, pp. 13151325, 2018. https://doi.org/10.1080/02602938.2018.1463354

[15] P. Dawson, M. Henderson, P. Mahoney, M. Phillips, T. Ryan, D. Boud, and E. Molloy, "What makes for effective feedback: staff and student perspectives," Assessment \& Evalu- 
Paper-Distance Education: An Investigation of Tutors' Electronic Feedback Practices during...

ation in Higher Education, vol. 44, no. 1, pp. 25-36, 2018. https://doi.org/10.1080/026029 38.2018.1467877

[16] K. Hyland and F. Hyland, "Feedback on second language students' writing," Language Teaching, vol. 39, no. 2, pp. 83-101, 2006. http://dx.doi.org/10.1017/S0261444806003399

[17] Y. Gülbahar and M. Adnan, "Faculty Professional Development in Creating Significant Teaching and Learning Experiences Online," Handbook of Research on Creating Meaningful Experiences in Online Courses, pp. 37-58, 2020. https://doi.org/10.4018/978-1-799 $\underline{8-0115-3 . c h 004}$

[18] L. Kyei-Blankson, E. Ntuli, and J. Blankson, Handbook of research on creating meaningful experiences in online courses. Hershey, PA: IGI Global, 2020. https://doi.org/10.4018/ 978-1-7998-0115-3

[19] R. M. Cutri and J. Mena, "A critical reconceptualization of faculty readiness for online teaching," Distance Education, vol. 41, no. 3, pp. 361-380, 2020. https://doi.org/10.1080/0 1587919.2020 .1763167

[20] I. Elola and A. Oskoz, "Supporting Second Language Writing Using Multimodal Feedback," Foreign Language Annals, vol. 49, no. 1, pp. 58-74, 2016. http://dx.doi.org/10.111 $\underline{\text { 1/flan. } 12183}$

[21] W. Alharbi, "E-Feedback as a Scaffolding Teaching Strategy in the Online Language Classroom," Journal of Educational Technology Systems, vol. 46, no. 2, pp. 239-251, 2017. https://doi.org/10.1177/0047239517697966

[22] T. Fu and H. Nassaji, "Corrective feedback, learner uptake, and feedback perception in a Chinese as a foreign language classroom," Studies in Second Language Learning and Teaching, vol. 6, no. 1, pp. 159-181, 2016. https://doi.org/10.14746/ssllt.2016.6.1.8

[23] C. Coll, M. J. Rochera, and I. de Gispert, "Supporting online collaborative learning in small groups: Teacher feedback on learning content, academic task and social participation," Computers \& Education, vol. 75, pp. 53-64, 2014. https://doi:10.1016/j.compedu.20 14.01.015

[24] L. S. VYGOTSKY, Mind In Society: Development of Higher Psychological Processes. Harvard UP, 1978.

[25] M. H. Long, "The Role of the Linguistic Environment in Second Language Acquisition," Handbook of Second Language Acquisition, pp. 413-468, 1996. https://doi.org/10.1016/B 978-012589042-7/50015-3

[26] L. S. Vygotskij, E. Hanfmann, G. Vakar, and J. Piaget, Thought and language. Cambridge: Mass. Institute of technology, 1962. https://doi.org/10.1037/11193-000

[27] L. A. Stern and A. Solomon, "Effective faculty feedback: The road less traveled," Assessing Writing, vol. 11, no. 1, pp. 22-41, 2006. https://doi.org/10.1016/j.asw.2005.12.001

[28] T. Lunt and J. Curran, “'Are you listening please?' The advantages of electronic audio feedback compared to written feedback," Assessment \& Evaluation in Higher Education, vol. 35, no. 7, pp. 759-769, 2010. http://dx.doi.org/10.1080/02602930902977772

[29] M. A. Alharbi, "Exploring the potential of Google Doc in facilitating innovative teaching and learning practices in an EFL writing course," Innovation in Language Learning and Teaching, vol. 14, no. 3, pp. 227-242, 2019. https://doi.org/10.1080/17501229.2019.15721 $\underline{57}$

[30] A. Bakla, "A mixed-methods study of feedback modes in EFL writing," Language Learning \& Technology, vol. 24, no. 3, pp. 107-128, 2020. https://doi.org/10125/44712

[31] M. Cavaleri, S. Kawaguchi, B. Di Biase, and C. Power, "How recorded audio-visual feedback can improve academic language support," Journal of University Teaching \& Learning Practice,vol. 16, no 4, pp. 1-19, 2020. https://doi.org/10.53761/1.16.4.6 
Paper-Distance Education: An Investigation of Tutors’ Electronic Feedback Practices during...

[32] K. J. Cunningham, "Student Perceptions and Use of Technology-Mediated Text and Screencast Feedback in ESL Writing," Computers and Composition, vol. 52, pp. 222-241, 2019. https://doi.org/10.1016/j.compcom.2019.02.003

[33] A. Susanti and A. Tarmuji, "Techniques of Optimizing Whatsapp as an Instructional Tool for Teaching EFL Writing in Indonesian Senior High Schools," International Journal on Studies in English Language and Literature, vol. 4, no. 10, pp. 26-31, 2016. http://dx.doi. org/10.20431/2347-3134.0410005

[34] S. S. Tseng and H. C. Yeh, "The impact of video and written feedback on student preferences of English speaking practice," Language Learning \& Technology, vol. 23, no. 2, pp. 145-158, 2019. https://doi.org/10125/44687

[35] H. Ai, "Providing graduated corrective feedback in an intelligent computer-assisted language learning environment," ReCALL, vol. 29, no. 3, pp. 313-334, 2017. https://doi.org/ 10.1017/S095834401700012X

[36] S. Ebadi and M. Rahimi, "Exploring the impact of online peer-editing using Google Docs on EFL learners' academic writing skills: a mixed methods study," Computer Assisted Language Learning, vol. 30, no. 8, pp. 787-815, 2017. https://doi.org/10.1080/09588221.2 $\underline{017.1363056}$

[37] K. L. Neumann and T. J. Kopcha, "Using Google Docs for Peer-then-Teacher Review on Middle School Students' Writing," Computers and Composition, vol. 54, pp. 1-16, 2019. https://doi.org/10.1016/j.compcom.2019.102524

[38] F. Harper, H. Green, and M. Fernandez-Toro, "Using screencasts in the teaching of modern languages: investigating the use of Jing ${ }^{\circledR}$ in feedback on written assignments," The Language Learning Journal, vol. 46, no. 3, pp. 277-292, 2015. http://dx.doi.org/10.1080/ 09571736.2015.1061586

[39] A. J. Cavanaugh and L. Song, "Audio feedback versus written feedback: Instructors' and students' perspectives," Journal of Online Learning and Teaching, vol. 10, no.1, pp. 122138, 2014.

[40] A. AbuSeileek and A. Abualsha'r, "Using peer computer-mediated corrective feedback to support EFL learners' writing,” Language Learning \& Technology, vol. 18, no.1, pp. 7695, 2014

[41] K. J. Cunningham, "APPRAISAL as a framework for understanding multimodal electronic feedback: Positioning and purpose in screencast video and text feedback in ESL writing," Writing \& Pedagogy, vol. 9, no. 3, pp. 457-485, 2018. https://doi.org/10.1558/wap.31736

[42] M. L. Silva, "Camtasia in the Classroom: Student Attitudes and Preferences for Video Commentary or Microsoft Word Comments During the Revision Process," Computers and Composition, vol. 29, no. 1, pp. 1-22, 2012. http://dx.doi.org/10.1016/j.compcom.2011.12. $\underline{001}$

[43] E. H. Alsolami, and T. Elyas, "Investigating Teachers' Corrective Feedback \& Learners' Uptake in the EFL Classrooms," International Journal of Educational Investigations, vol. 3, no. 1, pp.115-132, 2016.

[44] J. Williams, "Tutoring and revision: Second language writers in the writing center," Journal of Second Language Writing, vol. 13, no. 3, pp. 173-201, 2004. https://doi.org/10.1016 lj.jslw.2004.04.009

[45] S. Özkul and D. Ortaçtepe, "The use of video feedback in teaching process-approach EFL writing," TESOL Journal, vol. 8, no. 4, pp. 862-877, 2017. https://doi.org/10.1002/tesj.362

[46] T. Heift, "Corrective feedback and learner uptake in CALL," ReCALL, vol. 16, no. 2, pp. 416-431, 2004. https://doi.org/10.1017/S0958344004001120 
Paper-Distance Education: An Investigation of Tutors’ Electronic Feedback Practices during...

[47] F. F. Ishtaiwa and I. M. Aburezeq, "The impact of Google Docs on student collaboration: A UAE case study," Learning, Culture and Social Interaction, vol. 7, pp. 85-96, 2015. http://dx.doi.org/10.1016/j.lcsi.2015.07.004

[48] R. Lyster and L. Ranta, "Corrective feedback and learner uptake: negotiation of form in communicative classrooms," Studies in Second Language Acquisition, vol. 19, no. 1, pp. 37-66, 1997. https://doi.org/10.1017/S0272263197001034

[49] T. Guasch, A. Espasa, and M. Martinez-Melo, "The art of questioning in online learning environments: the potentialities of feedback in writing," Assessment \& Evaluation in Higher Education, vol. 44, no. 1, pp. 111-123, 2018. https://doi.org/10.1080/02602938.20 $\underline{18.1479373}$

[50] J. McCarthy, "Evaluating written, audio and video feedback in higher education summative assessment tasks," Issues in Educational Research, vol. 25, no. 2, pp.153-169.

[51] Z.-gang Ge, "Exploring e-learners' perceptions of net-based peer-reviewed English writing," International Journal of Computer-Supported Collaborative Learning, vol. 6, no. 1, pp. 75-91, 2011. https://doi.org/10.1007/s11412-010-9103-7

[52] P. Mahoney, S. Macfarlane, and R. Ajjawi, "A qualitative synthesis of video feedback in higher education," Teaching in Higher Education, vol. 24, no. 2, pp. 157-179, 2018. . https://doi.org/10.1080/13562517.2018.1471457

[53] J. Poston, S. Apostel and K. Richardson, "Using Microsoft Teams to Enhance Engagement and Learning with Any Class : It's Fun and Easy," Pedagogic on Conference Proceedings, vol. 6, pp. 1-7. 2020. https://encompass.eku.edu/pedagogicon

[54] A. R. Rojabi, "Exploring EFL Students' Perception of Online Learning via Microsoft Teams: University Level in Indonesia," English Language Teaching Educational Journal, vol. 3, no. 2, p. 163, 2020. https://doi.org/10.12928/eltej.v3i2.2349

[55] Z. (V. Zhang and K. Hyland, "Student engagement with teacher and automated feedback on L2 writing," Assessing Writing, vol. 36, pp. 90-102, 2018. https://doi.org/10.1016/j.asw .2018 .02 .004

[56] Y. Zheng and S. Yu, "Student engagement with teacher written corrective feedback in EFL writing: A case study of Chinese lower-proficiency students," Assessing Writing, vol. 37, pp. 13-24, 2018. https://doi.org/10.1016/j.asw.2018.03.001

[57] N. Storch and G. Wigglesworth, "Learners' processing, uptake, and retention of corrective feedback on writing: case studies," Studies in Second Language Acquisition, vol. 32, no. 2 , pp. 303-334, 2010. https://doi.org/10.1017/s0272263109990532

[58] N. E. Winstone, R. A. Nash, M. Parker, and J. Rowntree, "Supporting learners' agentic engagement with feedback: a systematic review and a taxonomy of recipience processes," Educational Psychologist, vol. 52, no. 1, pp. 17-37, 2016. https://doi.org/10.1080/0046152 $\underline{0.2016 .1207538}$

[59] M. Huxham, "Fast and effective feedback: are model answers the answer?," Assessment \& Evaluation in Higher Education, vol. 32, no. 6, pp. 601-611, 2007. https://doi.org/10.1080 102602930601116946

[60] M. Ross and M. Welsh, "Formative Feedback to Improve Learning on a Teacher Education Degree using a Personal Learning Environment ," International Journal of Emerging Technologies in Learning (iJET), vol. 2, no. 3, pp. 1-6. 2007.

\section{Authors}

Atef Odeh AbuSa'aleek is an Assistant professor of Applied Linguistics, Department of English, College of Education, Majmaah University, Al-Majmaah, 11952, 
Paper-Distance Education: An Investigation of Tutors' Electronic Feedback Practices during...

Saudi Arabia. His research interests are Applied Linguistics, Internet Linguistics, CALL, EFL writing, and electronic feedback.

Abdullah N. Alotaibi is an Assistant professor of Applied Linguistics, Department of English, College of Science and Humanities in Rumah, Majmaah University, AlMajmaah, 11952, Saudi Arabia. His research interests are second language Learning, L2 phonetics and phonology, and developmental speech perception (email: an.otaibi@mu.edu.sa, https://orcid.org/0000-0002-1597-9480).

Article submitted 2021-03-10. Resubmitted 2021-10-11. Final acceptance 2022-01-05. Final version published as submitted by the authors. 